\title{
Vízoldaható antioxidánsok döntéshelyzetben
}

\author{
SZARKA András* \\ Budapesti Müszaki és Gazdaságtudományi Egyetem, Alkalmazott Biotechnológia és Élelmiszer-tudományi tanszék, Biokémiai \\ és Molekuláris Biológiai Laboratórium, Müegyetem rakpart 3. 1111 Budapest, Magyarország
}

\section{Bevezetés}

A növényi és állati (emberi) sejtek két legnagyobb mennyiségben előforduló vízoldható antioxidánsa a C-vitamin és a glutation (GSH). A növényi sejtek a C-vitamint millimólos koncentrációban tartalmazzák, míg a GSH koncentrációja egy nagyságrenddel kisebb ${ }^{1}$. Állati és humán sejtekben ez pont fordítva van a GSH koncentráció eléri a millimólos nagyságrendet, míg a C-vitamin plazmában mért koncentrációja $100 \mu \mathrm{M}$-nál tetőzik ${ }^{2}$. Bár mindkét vegyület markáns antioxidáns sajátságokat mutat, élettani hatásuk ettől jóval szélesebb.

\section{A C-vitamin legfontosabb élettani funkciói}

A C-vitamin fiziológiai pH értéken aszkorbát anion formában van jelen ezért legtöbbször így kerül említésre. Az aszkorbát biológiai funkciójával kapcsolatos ismeretünk folyamatosan bővül, azonban minden eddig megismert funkciója kiváló elektrondonor sajátságából fakad. Az aszkorbát így hatékonyan eliminálja a reaktív oxigén (ROS) és nitrogén származékokat ${ }^{3}$. Az állati (humán) szervezetben, sejtekben a 2-oxoglutarát függő dehidrogenázok kofaktoraként részt vesz a karnitin, a katekolaminok bioszintézisében, illetve az extraceluláris mátrix fehérjéinek, mint például a kollagén poszt-transzlációs módosításában ${ }^{4}$. Igen valószínü, hogy szerepet kap egy másik poszt-transzlációs módosítás, a diszulfid hidak kialakulásában is ${ }^{4-6}$. A közelmúltban funkcióit kiterjesztették a sejtmagra is, ahol epigenetikus szerepet tölt be a DNS és a hiszton demetilázok kofaktoraként ${ }^{7}$, illetve a vas tartalmú 2-oxoglutarát-függő enzimek szerepet kapnak a HIF-1 (le)szabályozásában is. Az aszkorbát mind sejt, mind szervezet szintjén befolyásolja a vas felvételét anyagcseréjét is.

A növényi sejtekben az aszkorbát számos szerepet tölt be a fotoprotekcióban ${ }^{8}$ úgy, mint: a $\mathrm{H}_{2} \mathrm{O}_{2}$ semlegesítése az aszkorbát peroxidáz (APX) aktivitáson keresztül, a ROS direkt semlegesítése, a hidrofób antioxidáns $\alpha$-tokoferol regenerációja ${ }^{9}$, a luminális aszkorbáton keresztül a fotorendszer II-nek történő elektron átadása, valamint a xantofil körben, mint a violaxantin deepoxidáz kofaktora szerepel. Ez utóbbi kör lehetővé teszi intenzív megvilágítás esetén a fényenergia hő formájában történő disszipálását, a fotoszintetikus apparátus védelme érdekében (nem fotokémiai kioltás) ${ }^{10}$. Az aszkorbát/dehidroaszkorbát (DHA) páros láthatóan szerepet játszik a sejtciklus szabályozásában. Az aszkorbát, a DHA és a monodehidroaszkorbát képes növelni a $\mathrm{G} 1$ fázisból $\mathrm{S}$ fázisba lépő sejtek arányát. Az állati sejtekhez hasonlóan aszkorbát kofaktorral rendelkező prolin hidroxiláz, felelős a növényekben a sejtfal hidroxiprolin gazdag glikoproteinjei hidroxilációjáért. A 2-oxoglutarát függő dioxigenázok ezen túl részt vesznek a flavonoidok bioszintézisében. Az aszkorbát továbbá olyan szerves savak prekurzora (oxálsav, L-treonát, L-tartarát), amelyek igen nagy mennyiségben fordulnak elö a gyümölcsökben ${ }^{11}$.

\section{A glutation legfontosabb élettani funkciói}

J. de Rey-Pailhade 1888-as kezdeti kísérleteit követően ${ }^{12,13}$ a glutationt Szent-Györgyi Albert egykori cambridgei professzora F.G. Hopkins írta le. Hopkins 1929-ben Nobel díjat kapott a glutationnal, illetve a vitaminokkal és más táplálkozási faktorokkal kapcsolatos kutatásaiért. Szent-Györgyi káposzta szöveteken végzett kísérletei során azt tapasztalta, hogy azok képesek az aszkorbinsavat oxidált formájából redukálni, miközben a glutation oxidálódik ${ }^{14}$. 1936-ban Hopkins és Morgan arra a megállapításra jutott, hogy a redukálószer nem más, mint a glutation ${ }^{15}$. A reaktív oxigénvegyületek biológiai fontosságának felismerésével az 1960-as években megnőtt az érdeklődés a glutation iránt. 1976-ban leírásra került, hogy az aszkorbát monodehidroaszkorbátból (egy elektronnal), vagy dehidroaszkorbátból (két elektronnal) történő regenerációja NADH, illetve GSH mint elektrondonorok terhére történik. Ezt követően az oxidált GSH, glutation reduktáz segítségével, NADPH elektrondonor felhasználásával regenerálódik. Az aszkorbát és a glutation ezzel a felfedezéssel fiziológiás kapcsolatba került ${ }^{16}$.

A GSH a legfontosabb tiol redox puffer, amely segít az intracelluláris redox homeosztázist fenntartani. Oxidatív stressz esetén a GSH revezibilis módon a fehérje tiol csoportokkal kevert diszulfidokat képez, annak érdekében, hogy megvédje az irreverzibilis fehérjeoxidációtól ${ }^{17}$. Ez egy reverzibilis fehérjemódosulás, amely révén a fehérjék funkciója visszaállítható, ha az intracelluláris redox állapot, az inzultust követően normalizálódik. A GSH nem-enzimes reakcióban is reagál az olyan ROS-kel, mint a szuperoxid, a $\mathrm{H}_{2} \mathrm{O}_{2}$, az NO, a hidroxil gyök, és a peroxinitrit ${ }^{18}$. Igaz, ez a kémiai reakció meglehetően lassú folyamat, azonban több enzim is alkalmas arra, hogy a peroxid redukcióját a GSH oxidációjához kösse. Fiziológiás körülmények között elsősorban a glutation peroxidázok (GPx) birkóznak meg a $\mathrm{H}_{2} \mathrm{O}_{2}$ terheléssel. Toxikológiai szempontból fontosak a glutation-S-transzferáz (GST), az enzimek, amelyek igen különböző elektrofil xenobiotikum detoxifikálására képesek GSH-S-konjugáció révén. A növények nehézfém 
szennyezés hatására GSH-ból és más homológ biotiolokból fitokelatinokat szintetizálnak, amelyek szufhidril oldalláncaik révén képesek a kadmiumhoz és más toxikus elemekhez kötődni, majd a vakuólába transzportálni azokat ${ }^{1}$.

\section{Az aszkorbát glutation függő regenerációja fiziológiás és stressz helyzetben}

Az aszkorbát miközben ellátja antioxidáns és enzim kofaktor szerepét elektronokat ad le aszkorbil gyök, majd DHA keletkezik belőle. Redukciójának rövid időn belül be kell következnie, különben a DHA végérvényesen elvész, a fiziológiás pH-n néhány perc alatt felnyíló laktongyürü miatt ${ }^{1}$. Korábban laboratóriumunkban elvégzett kísérletek alapján arra a következtetésre jutottunk, hogy a növényi mitokondriális elektrontranszfer lánc nemcsak az aszkorbát bioszintézisében, de a DHA mitokondriális redukciójában is részt vesz. Mindkét folyamatban fontos szerepet játszanak a növényi mitokondrium nagyméretű számos fehérjealegységből álló és különböző fémionokat tartalmazó légzési komplexei (I-IV). Légzési szubsztrátokkal és gátlószerekkel végzett kísérletek alapján a légzési elektrontranszfer lánc-függő DHA redukció helyszíne a mitokondriális mátrix, elektrondonora a komplex II. Komplex II szubsztráttal millimolos aszkorbát koncentráció érhető el a mitokondriális mátrixban. A mátrixban a DHA redukció során keletkezett aszkorbát kijut a mitokondriumból és a membránközti térben hozzájárul a komplex IV elektronellátásához, amelynek fontos szerepe lehet stresszhelyzetben a növények életképességének fenntartásában ${ }^{19}$. Ezt a feltételezésünket sikerült igazolnunk mitokondriális III-as komplex mutáns ppr-40 lúdfü estében. A mutációt hordozó növényeknél, a III-as komplexnél bekövetkező elektron áramlási blokk, csökkent mértékü légzést (elektrontranszfert) okoz, amely egy kompenzációs mechanizmust indít el. A kompenzációs mechanizmus eredményeként fokozódik a IV-es komplex (citokróm c oxidáz, $\mathrm{CCO}$ ) és az alternatív oxidáz (AOX) aktivitása, illetve jelentős mértékben megnő a IV-es komplex alternatív elektrondonoraként viselkedő aszkorbát fogyása. Így az aszkorbát nemcsak antioxidánsként, de az alap anyagcsere részeként is képes hozzájárulni a (komplex III) sérült növények életképességének növeléséhe $z^{20}$. Így az sem okozott különösebb meglepetést, amikor azt találtuk, hogy a ppr-40 növényeket mind mitokondriális, mind sejtszinten jóval kisebb és oxidáltabb C-vitamin szint jellemzi, mint a vad típusú lúdfüvet ${ }^{21}$. Az aszkorbát (DHA-ból történő) regenerációjáért felelős GSH függő folyamat, az aszkorbát-glutation ciklus minden enzimének aktivitása megemelkedik a ppr-40 mutáns növényekben és az azokból izolált mitokondriumokban, a vad típusú növényekhez viszonyítva. A ciklus enzimeinek emelkedett aktivitása együtt jár a redukcióhoz elektronokat szolgáltató GSH mitokondriális szintjének emelkedésével a mutáns növényekben. A C-vitamin bioszintézis utolsó lépését katalizáló, mitokondriális L-galaktono-1,4-lakton dehidrogenáz enzim mRNS szintje nem változik meg a ppr-40 mutáns növényekben, azonban aktivitása mintegy 25\%-kal megemelkedik, feltehetően az oxidáltabb redox állapotú elektronakceptor citokróm c miatt. A ppr-40 növényekben mérhető jelentősen alacsonyabb teljes C-vitamin szint és a még jelentősebb mértékben csökkent és oxidáltabb mitokondriális C-vitamin szint azt jelzi, hogy a megnövekedett regenerációs és szintetikus kapacitás is kevésnek bizonyul a III-as komplexnél bekövetkező elektronáramlási blokk következtében kialakuló oxidatív stressz és fokozott aszkorbát fogyasztás kompenzálására ${ }^{21}$. Ahogy azt korábban láttuk a növényi mitokondriumban eddig két aszkorbát regenerációs útvonalat írtak le a GSH függő azkorbát-glutation ciklust ${ }^{1}$, illetve a mitokondriális komplex II-höz kapcsolt redukciót ${ }^{19}$. A két útvonal DHA redukcióhoz való hozzájárulása sokáig ismeretlen volt. A közelmúltban meghatároztuk a komplex II és a glutation (GSH) függő folyamatok mitokondriális DHA redukcióhoz való hozzájárulásának mértékét növényi sejtekben. A mitokondriális DHA redukcióhoz a GSH függő folyamatok mintegy 20\%-ban járulnak hozzá, míg a komplex II függó redukció ettől lényegesen nagyobb mértékü. Ezek alapján megállapítottuk, hogy a mitokondriális elektrontranszfer lánc szerepét a mitokondriális aszkorbát reciklálásban eddig jelentősen alábecsülték ${ }^{22}$.

Eredményeink arra utalnak, hogy a növényi mitokondriumban létezik egy aszkorbát/DHA redox párból álló komplex III-at megkerülő elektrontranszfer útvonal (1. ábra). Az útvonal képes lehet stresszhelyzetekben az elektrontranszfer lánc elemeinek redukáltságát csillapítani, ami egyrészt direkt módon csökkenti a reaktív oxigénvegyületek keletkezését, másrészt az aszkorbát szint fokozásával növeli az antioxidáns védelem hatásfokát. A kerülőút limitáló lépése nagy valószínüség szerint az aszkorbát mátrixból történő kijutása. Ezt bizonyítja, hogy a DHA redukció eredményeként keletkező aszkorbát a mátrixhoz képest jelentős késedelemmel jelenik csak meg az extramitokondriális térben (mitokondriális membránközti térben) $)^{23}$.

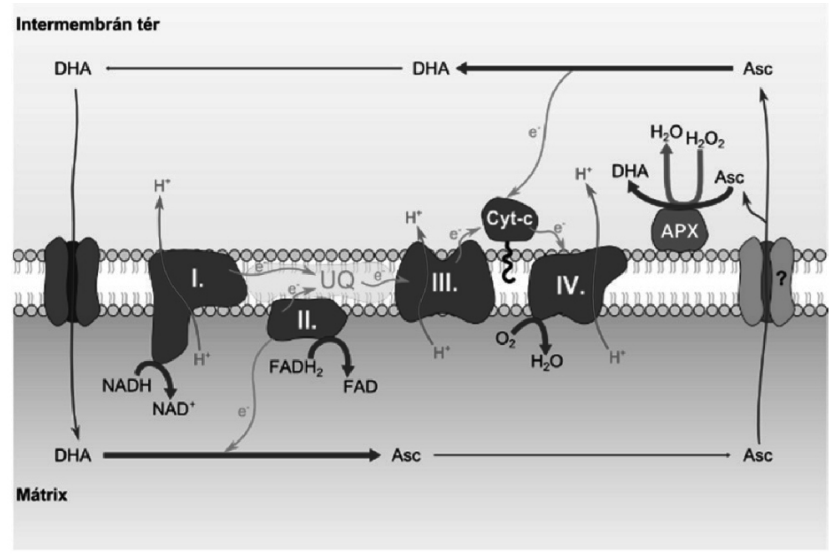

1. ábra Az aszkorbát/DHA kör hipotetikus összefoglaló modellábrája.

Minden eddig említésre került stresszhelyzetben az aszkorbát, annak emelkedett szintje védelmet jelentett a növény számára, növelte túlélési esélyeit. Fontos megjegyeznünk, hogy az eddig említésre került stresszhelyzetek mind egytől egyig abiotikus stresszhelyzetek voltak. Vajon más helyzetet jelent-e a 
biotikus stressz? Az inkompatibilis növény-patogén interakció egyik korai eseménye az oxidatív kitörés. A kitörés alatt hirtelen megugró ROS szint egyrészről kedvező hatású. A ROS másodlagos hírvivőként koordinálja a védelmi gének aktiválását és hozzájárul a további védekezéshez. Ugyanakkor kritikus a ROS szint igen precíz szabályozása, annak érdekében, hogy elkerüljük a nem kívánt toxicitást. Ahogy azt korábban már láttuk az aszkorbát a növények legnagyobb mennyiségben előforduló vízoldható antioxidánsaként kiemelt szerepet játszik a ROS szint kiegyensúlyozásában (a ROS eliminálásában) ${ }^{1}$. Az aszkorbát szint szabályozása ezért fontos szerepet tölthet be a ROS szint finomra hangolásában a növény-patogén interakció korai szakaszában. Annak érdekében, hogy kiderítsük, hogy ez az interakció miként befolyásolja az aszkorbát bioszintézisét, reciklálását és szintjét lúdfü sejteket kezeltünk egy növénypatogén baktérium két különböző harpin fehérjéjével (HrpZpto and HrpWpto), mintegy mímelve a bakteriális fertőzést ${ }^{24}$. Mindkét fehérje jól definiált ROS kiugrást eredményezett, amellyel párhuzamosan jelentős mértékben megnőtt az alternatív oxidáz (AOX1a) kifejeződése. A C-vitamin szintézis sebesség meghatározó lépését katalizáló GDP-L-galaktóz foszforilázt kódoló egyik paralóg gén a vtc5 kifejeződése is markánsan megemelkedett a ROS ugrást követően. Az elözőekhez hasonlóan az aszkorbát bioszintézis utolsó lépését katalizáló galaktono-1,4-lakton dehidrogenáz és a $\mathrm{H}_{2} \mathrm{O}_{2}$ eliminációban kulcsszerepet játszó aszkorbátperoxidáz aktivitása, illetve az aszkorbát és a glutation szintje is megnőtt a harpin kezelés következtében megnövekedett ROS szint hatására. Mindezen tényezők jó eséllyel hozzájárulhatnak a programozott sejthalál általunk tapasztalt jelentős mértékü mérsékléséhez. Nem utolsó sorban a redox egyensúly finomra hangolását, mint egy új funkciót vethetünk fel a vtc5 gén számára ${ }^{24}$.

\section{A glutation és a mitokondrium szerepe a gyógyszer- toxicitás kiváltotta sejthalál folyamatában}

$\mathrm{Az}$ acetaminofen (APAP) kiváltotta májkárosodás klinikailag releváns, alaposan tanulmányozott, gyorsan kiváltható, így farmakológiai és toxikológiai tesztetalonná vált. Ugyanakkor az APAP májkárosításának mechanizmusa összetett, az általa kiváltott sejtelhalás és májkárosodás számos aspektusa mind a mai napig ismeretlen. Egér máj eredetü mikroszómális vezikulák esetében igazoltuk, hogy in vivo APAP és a GSH bioszintézist gátló butionin-szulfoximin (BSO) kezelés hatására a mikroszómális GSH szint markánsan csökken ${ }^{25}$. Az APAP $\mathrm{N}$-acetil-p-benzokinon iminné (NAPQI) történő konverziója, illetve a NAPQI GSH terhére történő konjugációja, majd a NAPQI-GSH kiürítése áll az extrém mértékü GSH depléció hátterében. A redukált GSH és fehérje tiolok részaránya APAP kezelést követően lényegesen kisebbnek bizonyult, a BSO kezelés ugyanakkor a mikroszómákban lényeges mértékben nem változtatta meg a redukált/teljes GSH arányt. APAP kezelés hatására jelentős mértékben megnövekedett az apoptotikus sejtek száma, azonban a nekrózis mennyiségileg jóval jelentősebb mértékü volt ${ }^{26}$. Ezt követően kimutattuk, hogy a nekroptózis és az apoptózis mellett egy harmadik programozott sejthalál típus, a ferroptózis is szerepet kap az APAP kiváltotta sejthalál folyamatában primer egér májsejtekben ${ }^{27}$. Eredményeink alapján a ferroptózis gátlószer, ferrostatin-1 védőhatása, nem a csökkent APAP-NAPQI metabolizmusból és nem a megváltozott GSH-val történő NAPQI konjugációból fakad. Az APAP kiváltotta sejthalál folyamatát gátolta a C- és E-vitamin. A C-vitamin, valamint a C-és E-vitamin kombinációjának védőhatása meghaladta a kizárólag önmagában adagolt E-vitaminét ${ }^{27}$.

A mitokondrium sejthalálban játszott fontos szerepe, illetve a C-vitamin védő hatása miatt kíváncsiak lettünk, arra, hogy a C-vitamin miként, milyen transzporterek segítségével jut be a mitokondriumba. Korábban két transzporter család tagjairól írták le, hogy részt vesz a C-vitamin biomembránokon keresztüli transzportjában ${ }^{2}$. A GLUT (SLC2), illetve az SVCT (SLC23) transzporter családok in silico lokalizációjának vizsgálatával megerősítettük a GLUT1 és az SVCT2 transzporterek mitokondriális lokalizációját, ugyanakkor megkérdőjeleztük a GLUT10 mitokondriális jelenlétét. Ezen túl eredményeink alapján valószínűsítjük két újabb, GLUT családtag, a GLUT9 és a GLUT11 mitokondriális elhelyezkedését, illetve felvetjük DHA transzportban való részvételüket ${ }^{28}$. Vizsgálatainkat mitokondriális DNS fosztott sejteken folytatva megállapítottuk, hogy a mitokondriális DNS hiány hatására, a mitokondriális oxidatív folding apparátus fontos eleme, az ALR (Augmenter of Liver Regeneration) fehérjeszintje jelentős mértékben megnő. Az ALR mennyisége nem mutatott változást a sejtek légzési komplex gátló és szétkapcsoló szerekkel történő kezelésére, ezért az ATP, illetve ROS szintek ALR fehérjeszintet szabályozó szerepe nem valószínü ${ }^{29}$. Az ALR részt vesz a mitokondriumok biogenezisében és fenntartásában, ezért könnyen elképzelhető, hogy szintjének megemelkedése a mitokondriális DNS fosztott, ń$^{0}$ sejtek adaptív válaszának egy része lehet, amely segít a mtDNS-ben kódolt fehérjék kiesése ellenére a mitokondriális belső membrán integritásának és a membránpotenciál megőrzésében. Így az ALR minden olyan esetben, amely a mtDNS számának csökkenésével jár, a mitokondriális betegségekben és az öregedés során előforduló mtDNS mutációk esetében is hozzájárulhat a mitokondriális funkciók fenntartásához. Eredményeink alapján, az ALR a gépezet egy fontos alkotója lehet, a mtDNS pedig fontos szabályozó szerepet tölthet be az ALR fehérjeszintjének szabályozásában.

\section{Gyakorlati felhasználási lehetőségek}

Ahogy láttuk a C-vitamin életről és halálról dönthet stresszhelyzetben, ami a növényi biotechnológia egyik kulcsvegyületévé teszi. Általa elérhetjük, hogy a fent ismertetett stressz hatásoknak ellenállóbb növényeket fejlesszünk ki, amely a szélsőséges időjárási és talajviszonyok jelentette kockázatot, kárt jelentős mértékben mérsékli. Minden aszkorbát metabolizmussal és szintjének szabályozásával kapcsolatos ismeret fontos szerepet játszhat szintjének, általunk, tudatosan kontrollált befolyásolásában. Érdekes módon minden eddigi a C-vitamin szintjébe történő 
tudatos mérnöki beavatkozás (amelyek elsősorban a bioszintetikus utat érintették) csak mérsékelt sikert értek el. Ezért különösen fontos szerepet játszhatnak a terület fejlődésében a C-vitamin reciklálásában elért eredményeink. $\mathrm{Az}$ oxidált formából történő reciklálás ugyanis igen hatékony módja a $\mathrm{C}$-vitamin szint befolyásolásának ${ }^{1,30}$.

\section{Hivatkozások}

1. Szarka, A; Tomasskovics, B; Bánhegyi, G. Int. J. Mol. Sci. 2012, 13, 4458-4483. https://doi.org/10.3390/ijms 13044458

2. Szarka, A; Lőrincz, T. Orvosi Hetilap 2013, 154, 1651-1656. https://doi.org/10.1556/OH.2013.29712

3. Mandl, J; Szarka, A; Bánhegyi, G. Br. J. Pharm. 2009 157, 1097-1110.

https://doi.org/10.1111/j.1476-5381.2009.00282.x

4. Szarka, A; Lörincz, T. Protoplasma 2014, 251, 489-497. https://doi.org/10.1007/s00709-013-0560-5

5. Szarka, A; Bánhegyi, G. BioMol Concepts 2011, 2, 379-390. https://doi.org/10.1515/BMC.2011.038

6. Szarka A, Stadler K, Jenei V, Margittai É, Csala M, Jakus J, Mandl J, Bánhegyi G. J Bioenerg Biomembr 2002, 34, 317-323. https://doi.org/10.1023/A:1020212720330

7. Banhegyi, G; Benedetti, A; Margittai, E; Marcolongo, P; Fulceri, R; Nemeth, CE; Szarka, A. Biochim Biphys Acta. Mol Cell Res 2014, 1843, 1909-1916. https://doi.org/10.1016/j.bbamcr.2014.05.016

8. Smirnoff, N. Philosophical Transactions of the Royal Society of London. Series B, Biological Sciences 2000, 355, 1455-1464. https://doi.org/10.1098/rstb.2000.0706

9. Foyer, CH; Shigeoka, S. Plant Physiology 2011, 155, 93-100. https://doi.org/10.1104/pp.110.166181

10. Demmig-Adams, B; Adams, WW. Trends in Plant Science 1996, 1, 21-26. https://doi.org/10.1016/S1360-1385(96)80019-7

11. DeBolt, S; Melino, V; Ford, CM. Annals of Botany 2007, 99, 3-8. https://doi.org/10.1093/aob/mcl236

12. De Rey-Pailhade, M.J. C. R. Acad. Sci. 1888, 106, 1683-1684.

13. Meister, A. Trends Biochem. Sci. 1988, 13, 185-188. https://doi.org/10.1016/0968-0004(88)90148-X

14. Szent-Györgyi, A. J. Biol. Chem. 1931, 90, 385-393.

15. Hopkins, FG; Morgan, EJ. Biochem. J. 1936, 30, 1446-1462. https://doi.org/10.1042/bj0301446

16. Foyer, CH; Halliwell, B. Planta 1976, 133: 21-25. https://doi.org/10.1007/BF00386001

17. Giustarini, D; Rossi, R; Milzani, A; Colombo R, Dalle-Donne I. J. Cell. Mol. Med. 2004, 8, 201-212. https://doi.org/10.1111/j.1582-4934.2004.tb00275.x

\section{Water soluble antioxidants in decision-making role}

The two major water soluble antioxidants of both plant and animal (human) cells are vitamin $\mathrm{C}$ and glutathione (GSH). While vitamin $\mathrm{C}$ can be found in millimolar concentration, the concentration of GSH is one order of magnitude lower. The situation is different in animal and human cells, the concentration of GSH reaches the millimolar range, however the concentration of vitamin $\mathrm{C}$ in plasma reaches its plateau at $100 \mu \mathrm{M}$. Although both compounds show remarkable antioxidant features their physiological role is much wider.
Jelenleg minden eredmény arra utal, hogy a reciklálás lehet a kulcs a C-vitaminszint tudatos befolyásolásában. Az acetaminofen túladagolás során nyert C- és E-vitaminnal kapcsolatos eredményeink, további sikeres állatkísérletek esetében nyert megerősítést követően alkalmasak lehetnek bizonyos májat károsító anyagok hatásának tompítására.

18. Aoyama, K; Watabe, M; Nakaki, T. J. Pharmacol. Sci. 2008, 108, 227-238.

https://doi.org/10.1254/jphs.08R01CR

19. Szarka, A.; Horemans, N.; Kovács, Z.; Gróf, P.; Mayer, M.; Bánhegyi G. Physiol. Plant. 2007, 129, 225-232. https://doi.org/10.1111/j.1399-3054.2006.00810.x

20. Zsigmond, L; Rigó, G; Szarka, A; Székely, Gy; Ötvös, K; Darula, Zs; Medzihradszky, KF; Koncz, Cs; Koncz, Zs; Szabados, L. Plant Physiol. 2008, 146, 1721-1737. https://doi.org/10.1104/pp.107.111260

21. Zsigmond, L; Tomasskovics, B; Deák, V; Rigó, G; Szabados, L; Bánhegyi, G; Szarka, A. Plant Physiol Biochem 2011, 49, 809-815. https://doi.org/10.1016/j.plaphy.2011.04.013

22. Szarka, A. Acta Physiol Plant 2013, 35, 3245-3250. https://doi.org/10.1007/s11738-013-1359-x

23. Szarka, A; Banhegyi, G; Asard, H. Antioxid Redox Signal, 2013, 19, 1036-1044. https://doi.org/10.1089/ars.2012.5059

24. Czobor, Á.; Hajdinák, P.; Szarka, A. Acta Physiol Plant 2017, 39, 62. https://doi.org/10.1007/s11738-017-2365-1

25. Nagy, G.; Kardon, T.; Wunderlich, L.; Szarka, A.; Kiss, A.; Schaff, Z.; Bánhegyi, G.; Mandl, J. Arch. Biochem. Biophys. 2007, 459, 273-279. https://doi.org/10.1016/j.abb.2006.11.021

26. Nagy, G; Szarka, A; Lotz, G; Dóczi, J; Wunderlich, L; Kiss, A; Jemnitz, K; Veres, Z, Bánhegyi; G, Schaff, Z; Sümegi, B; Mandl, J. Toxicol Appl Pharmacol. 2010 243, 96-103. https://doi.org/10.1016/j.taap.2009.11.017

27. Lörincz, T; Jemnitz, K; Kardon, T; Mandl, J; Szarka, A. Pathol Oncol Res. 2015, 21, 1115-1121. https://doi.org/10.1007/s12253-015-9946-3

28. Szarka, A; Balogh, T. J Theor Biol 2015, 365, 181-189. https://doi.org/10.1016/j.jtbi.2014.10.015

29. Balogh, T; Lőrincz, T; Stiller, I; Mandl, J; Bánhegyi, G; Szarka, A. Pathol Oncol Res. 2016, 22, 431-437. https://doi.org/10.1007/s12253-015-0020-y

30. Chen, Z.; Young, T.E.; Ling, J.; Chang, S.C.; Gallie, D.R. Proc. Natl. Acad. Sci. USA 2003, 100, 3525-3530. https://doi.org/10.1073/pnas.0635176100

Ascorbate, while scavenges reactive oxygen species ROS and functions as electron donor for different enzymes, is oxidized to monodehydroascorbate and then to dehydroascorbate (DHA). DHA is very unstable and only ascorbate possesses antioxidant and free radical scavenger properties. Thus DHA must be reduced back to ascorbate, otherwise under physiological conditions it is lost within minutes. The reduction of DHA clearly plays important role in the maintenance of sufficient level of ascorbate. In plant mitochondria two DHA reducing mechanisms, the 
GSH-dependent and the mitochondrial electron transfer chain dependent ascorbate recycling have been characterized. On the base of the parallel determination of mitochondrial GSH content and ascorbate production upon DHA addition, GSH (consumption) is responsible for the 20 $\%$ of ascorbate production. Almost $90 \%$ enhancement of ascorbate production could be provoked by the addition of Complex II substrate succinate which could be almost totally prevented by the concomitant addition of malonate or TTFA. On the base of these results, the importance of mitochondrial Complex II compared to GSH-dependent mechanisms in mitochondrial ascorbate recycling has been underestimated so far. A block of electron flow at complex III is presented in the Arabidopsis ppr40-1 mutant that can be characterized by higher level of ROS generation and sensitivity to different abiotic stresses. The activity of the ascorbate biosynthetic enzyme, L-galactono-1,4-lactone dehydrogenase (GLDH) was elevated in mitochondria isolated from these mutant plants. In addition increased activities of the enzymes of ascorbate-glutathione cycle and elevated glutathione (GSH) level were observed in the mutant mitochondria. Lower ascorbate and ascorbate plus DHA contents were detected at both cellular and mitochondrial level. Moreover, the more oxidized mitochondrial redox status of ascorbate in the ppr40-1 mutant indicated that neither the enhanced activity of GLDH nor Foyer-Halliwell-Asada cycle could compensate for the enhanced ascorbate consumption in the absence of a functional respiratory chain. Ascorbate may also play important role during the plant-pathogen interaction. An early event of the incompatible plant-pathogen interactions is an oxidative burst. On one hand, the ROS generated during oxidative burst is advantageous. ROS can serve as secondary messengers mediating defence gene activation and establishment of additional defences. On the other hand, the concentration of ROS must be carefully regulated to avoid undesired cellular cytotoxicity. The regulation of ascorbate level, can be an important point of the fine-tuning of ROS level during the early phase of plant-pathogen interaction. Thus we challenged Arabidopsis thaliana cells with two different harpin proteins (HrpZpto and HrpWpto). HrpZpto and HrpWpto treatments caused a well-defined ROS peak. The expression of the vtc5, one of the paralog genes that encode the rate limiting enzyme of ascorbate biosynthesis, followed the elevation of ROS. Similarly, the activity of ascorbate peroxidase, GLDH and the level of ascorbate and glutathione also followed the elevation of ROS due to harpin treatment. The enhanced expression of vtc5, the elevated activity of GLDH, and the increased level of ascorbate and glutathione all can contribute to the mitigation or absence of programmed cell death. Finally, a new function, the finetuning of redox balance during plant-pathogen interaction, can be proposed to vtc5.

Acetaminophen (APAP) induced liver injury is clinically relevant, well studied, and can be rapidly induced, therefore it has become a standard model in the pharmacology and toxicology. However the mechanism of APAP hepatotoxicity is extremely complex, thus many aspects of APAP-induced cell death and liver injury are still unknown. The major part of APAP is conjugated with glucuronic acid or with sulphate and excreted however a small fraction is metabolized by cytochrome P450 enzymes to $\mathrm{N}$-acetyl-p-benzoquinone imine (NAPQI). This highly reactive metabolite reacts rapidly with GSH causing extensive GSH depletion. The recently described form of programmed cell death, ferroptosis can be induced by agents causing GSH depletion or the inhibition of GPX4. Since NAPQI this highly reactive metabolite of APAP induces a cell death which can be characterized by GSH depletion, GPX inhibition and caspase independency the involvement of ferroptosis in acetaminophen induced cell death has been investigated. In the case of acetaminophen treated primary mouse hepatocytes the significant elevation of cell viability could be observed upon ferrostatin-1 treatment. Similar to ferrostatin-1 treatment, the addition of the RIP1 kinase inhibitor necrostatin-1 could also elevate the viability of acetaminophen treated primary hepatocytes. Ferrostatin-1 has no influence on the expression of CYP2E1 or on the cellular GSH level which suggest that the protective effect of ferrostatin-1 in APAP induced cell death is not based on the reduced metabolism of APAP to NAPQI or on altered NAPQI conjugation by cellular GSH. Our results suggest that beyond necroptosis and apoptosis a third programmed cell death, ferroptosis is also involved in acetaminophen induced cell death in primary hepatocytes. 